\title{
Kerk en teologie in die postmoderne tyd
}

\author{
P W du Toit \& I J J Spangenberg \\ Departement Ou Testament \\ Universiteit van Suid-Afrika
}

\begin{abstract}
Church and theology in the postmodern era

The postmodern era has wide implications for church and theology. This study is an endeavour to participate in the discourse on these implications. It reflects on what is entailed by postmodernism and how the new era influences church and theology. It also reflects on the interpretation of the Bible, the status of the Reformed confessions and the dialogues in which pastors engage in their congregations.
\end{abstract}

\section{INLEIDING}

Vir diegene wat met hulle oor op die kerkgrond en die oog in die sekulêre pers leef, behoort dit duidelik te wees dat die Christelike geloof en die Christelike teologie 'n paradigmaverandering beleef. Gesprekke met lidmate, medekollegas en ander persone maak 'n mens intens bewus daarvan dat die wêreld waarin baie van ons grootgeword het en die wêreld waarin ons tans leef, radikaal van mekaar verskil. Pieterse (1993:15) maak die volgende opmerking in hierdie verband: "Ons is nou in 'n oorgangstydperk wat ons beslis sal lei na 'n nuwe era, 'n nuwe geestestroming in die wêreldgeskiedenis. Ons kan dit nie oorsien nie, ons het nie ' $n$ behoorlike naam daarvoor nie (daarom word dit nog net as postmodern aangedui), en die kenmerke daarvan is vaag. Maar die dagbreek van hierdie nuwe tydvak het gedaag." 
Dockery (1995:13) stel dit weer soos volg:

As we move into the twenty-first century, a new way of viewing the world has emerged. The "modern" way of thinking, that dominated the nineteenth and twentieth centuries, has become obsolete. These modern ideas no longer seem relevant. The twenty-first century will by characterized as the "postmodern age." This postmodern world becomes the new challenge for the evangelical church.

\section{DIE POSTMODERNE TYD}

Daar bestaan verskillende sienswyses, beskrywings en menings oor wat postmodernisme behels (vgl De Villiers 1991:146; Kotze 1992:28, 1995:20; Dockery 1995:13,14; Van Aarde 1990:294). Een aspek waaroor daar egter eenstemmigheid is, is dat mense in die postmoderne tyd intens bewus geraak het daarvan dat daar nie 'n objektiewe kenbare wêreld en absoluut verifieerbare kennis van hierdie wêreld bestaan nie. In die postmoderne tyd word die modernistiese siening van kennis nie meer aanvaar nie. Daar bestaan nie 'n stel absolute, altydgeldende, onveranderlike waarhede en sekerhede wat oor tydgrense heen en in verskeie situasies dieselfde bly nie. Hierdie sekerhede bestaan ook nie onafhanklik van die identiteit van die navorser nie (Henry 1995:42).

'n Uitstaande kenmerk van postmoderne tyd is dus die epistemologiese vertrekpunt dat objektiewe kennis onmoontlik is. Die feit dat mense vanuit verskillende hoeke waarneem, na objekte kyk en dit beskryf, het die besef laat posvat dat die wêreld om ons meerdimensioneel is (Gergen 1994).

Omdat konstruktivisme en die sosiale konstruksie-diskoers dominante diskoerse in die postmoderne tyd is, en taal ook vanuit 'n postmodernistiese vertrekpunt anders beskou word, is dit nodig om eerstens hieraan aandag te gee. Dit is duidelik dat as 'n keuse vir 'n sosiaal konstruktivistiese epistemologie gemaak word, dit implikasies het vir die verstaan van teologie as wetenskap, die verstaan van die belydenisskrifte, asook hoe die Bybel as basisdokument van die Christelike geloof gehanteer behoort te word. Om die waarheid te sê, dit het implikasies vir kerk wees in die wydste sin van die woord. 


\subsection{Konstruktivisme}

Van die belangrikste eksponente van die konstruktivisme is die skrywers Maturana en Varela $(1980,1987)$ en Von Foerster (1984a, 1984b), wat die vraag na "wat" ons kan weet en "hoe" ons kan weet vanuit 'n biologiese en neurologiese vertrekpunt ondersoek. Konstruktivisme kan beskou word as die biologiese voorloper van die sosiale konstruksieteorie.

Die slotsom waartoe hulle kom, is dat die mens as biologiese en neurologiese wese struktuurgedetermineerd is. Mense kan slegs waarneem en handel volgens dit wat hulle struktuur (hulle biologiese en neurologiese prosesse) hulle toelaat. As biologiese en neurologiese wese is elke mens dus waarnemend en interpreterend besig. Voorts beskryf mense wat hulle waarneem deur middel van hulle spesifieke taal (woorde en simbole).

Die gevolg hiervan is dat mense nie die werklikheid objektief waarneem nie, want wat hulle waarneem, word in die eerste en laaste instansie deur hulle biologiese struktuur bepaal. Ons kennis en die objekte wat ons meen dat ons waarneem, is nie 'n onfeilbare weergawe van die werklikheid nie, maar eintlik net konstrukte van die werklikheid geformuleer in terme van ons taal. Hierdie konstrukte is voorts die produkte van die

aktiwiteite van ons senuweesisteem. Immanuel Kant (1724-1804) het reeds daarop gewys hoe die eienskappe van die kenner sy kennis beïnvloed. Von Foerster (1984a:288) stel dit so: "The environment as we perceive it is our invention."

Wat ons voorts in ag moet neem, is dat ons kennis van die werklikheid, medebepaal word deur die teorieë wat ons hanteer. Hierdie teorieë hou weer direk verband met ons taalkonstruksies. Die betekenis wat ons aan dinge toedig, is dus nie objektief nie, want verskillende mense neem vanuit verskillende hoeke waar en beskryf wat hulle waarneem in terme van die teorieë wat hulle ontwerp het. Na regte bestaan daar 'n veelheid van waarnemings en interpretasies.

\subsection{Sosiale konstruksieteorie}

Volgens die postmoderne insig in hoe ons tot kennis kom, is dit duidelik dat kennis altyd kontekstueel, lokaal maar tegelykertyd ook pluralisties is. Die postmoderne insig in kennis stel dat enige vorm van kennis (ook teologiese kennis) die produk is van sosiale diskoerse (vgl Kotze 1995:30-60). 
Volgens die sosiale konstruksieteorie is kennis en verstaan (ook teologiese kennis en verstaan) sosiale konstrukte met onderhandelde betekenis wat in menslike taalkonstruksies realiseer, of gekonstrueer word, en daarom kan kennis en woorde nie weerspieëlings van die werklikheid wees nie. Anders gestel: Die sosiale konstruksieteorie beskou alle menslike oortuigings/beskouings/opvattings oor die wêreld as sosiaallinguistiese uitvindings wat deur mense in sosiale interaksie gemaak word. Dit is dus nie beskrywings van 'n objektiewe realiteit nie (Hoffman 1990). Dinge en gebeure het nie intrinsieke betekenis nie. Daar is slegs 'n voortdurende interpretasie van die wêreld. In die woorde van die Ou-Testamentikus Brueggemann (1993:8): "Our knowing is inherently contextual .... It is now clear that what one knows and sees depends upon where one stands or sits."

Volgens die postmoderne epistemologie konstrueer plaaslike gemeenskappe hulle eie waarhede. Alle kennis, ook teologiese en wetenskaplike kennis is dus verwant aan en deel van plaaslike en kulturele diskoerse. Kennis en verstaan word dus beskou as produkte van sosiale aktiwiteit (Kotze 1992:9). Kennis (ook teologiese kennis) is dus dit waaroor ons in en deur taal ooreengekom het. Teologie en teologiese kennis is dus mensewerk, omdat dit konstrukte van mense is. Dit wat in teologie voortgebring word, is menslike konstrukte van die werklikheid.

'n Altydgeldigende en objektiewe lees en interpretasie van Bybelse tekste is dus onmoontlik. Alle kennis, insluitende kennis van Bybelse tekste, is die resultaat van 'n sosiale konstruksieproses. Du Toit (1988) wys daarop dat die postmoderne diskoers ons dwing om nuut om te gaan met tekste en die interpretasie daarvan en dat ons in gedagte moet gehou dat die interpretasie van tekste nie 'n suiwer objektiewe oefening is nie, maar dat subjektiewe, kontekstuele en misterieuse aspekte ook 'n rol speel. Objektiewe betekenis van woorde bestaan ook nie.

Daar is wel 'n aanwysbare teks, maar ons sosiaal gekonstrueerde diskoerse oor hierdie teks kom nie presies ooreen, of weerspieël nie presies hierdie teks in sy kompleksiteit nie. Teologiese diskoerse is altyd aan die beweeg, nooit onbuigsaam nie en altyd voorlopig. Die kerk se verstaan van God verander met verloop van tyd en hierdie verandering hang saam met die veranderinge in ons kultuur - selfs al hou die kerk aan 'n aanwysbare kanonieke Bybelteks vas (Van Aarde 1995). 
Die volgende aanhaling van Efran \& Lukens (1985:25) is dus 'n gepaste opmerking wat by die lees van hierdie artikel (en enige ander geskrewe stuk) in gedagte gehou moet word:

Frankly, you are not now reading our article - you are using the words we wrote to talk to yourself in a way that is determined by, and congruent with, your particular structure. You will use what we have written for your own "purposes", and there is nothing at all we can do about that.

\subsection{Die belangrikheid van taal}

Die Bybel en belydenisskrifte kom na ons toe in menslike taal. Volgens die postmoderne denkraamwerk konstrueer ons die werklikheid deur middel van taal. Toegepas op godsdiens en teologie moet ons dus sê dat, wanneer ons oor God praat, ons metafore en analogieë gebruik om oor 'n werklikheid te praat wat ons verstand te bowe gaan (vgl Van Huysteen 1989:775). God kan nie rasioneel bemeester word nie (Bottum 1994). Van Niekerk (1994:287) stel dit so:

In die teologie praat ons oor God soos ons dikwels in die wetenskap daarop aangewese is om oor die wêreld te praat: interpretatief, metafories, modelmatig - kortom: analogies. Ons ken God so min "finaal" soos wat moderne kernfisici meen dat hulle die atoom "volledig" kan beskryf. Teologie, omdat dit analogiese spreke is, is ' $n$ immer aflatende proses van interpretasie.

Vanuit 'n postmoderne denkraamwerk word taal ook anders beskou, deurdat daar 'n wantroue gekom het in taal as die draer van waarheid. Kotze (1992:10) sê: "Wetenskap en kennis as die vrugte van wetenskaplike arbeid is dus in die taaldomein geleë en is as sodanig betekenis wat sosiaal in taal geskep word. Dit is nie weergawes van die werklikheid nie, maar eerder sosiale konstrukte oor die werklikheid."

Wat jy as mens waarneem en beskryf, is bloot jou eie konstrukte wat jy verwoord. Dit beteken dat daar ' $n$ veelheid van kennis ten opsigte van die werklikheid bestaan en wat die predikant instaat stel om alternatiewelik te kan dink en te kan optree. Sekulêre en 
godsdienstige beelde verander oor tyd. Volgens die postmoderne sosiale konstruksiediskoers kan die intrinsieke betekenis van byvoorbeeld 'n metafoor soos die "regering van God" of die "wil van God" nie 'n gefikseerde betekenis hê wat geslagte, tyd en kulture transendeer nie. Wanneer ons die "regering van God" in ons lewe ervaar en taal gebruik om hierdie ervaring uit te druk, gaan ons 'n voortgaande metafoorskeppende proses binne, waar beide ons diskoerse en onsself verander. Alle kennis en so ook kennis van die teologiese metafoor "regering van God" is 'n linguistiese konstruksie (Botha 1998:130). Gelowiges se verstaan van die "wil van God" verander saam met metaforiese veranderinge in hulle kultuur (Van Aarde 1995). Woorde se betekenis is dus nooit finaal nie. Aan woorde kleef daar 'n voorlopigheid en 'n begrensdheid (vgl Dill 1996:244).

Dill (1996:246) se opmerking in dié verband is insiggewend: "Taal konstitueer ons lewenservarings - ons ervaar dinge op sekere wyses as gevolg van die taal waarin ons leef - byvoorbeeld gevoelens is nie biologies nie, maar bestaan kultureel - as 'n kultuur nie 'n bepaalde emosie in sy taal het nie, word daardie emosie nie ervaar nie."

\section{TEOLOGIE EN DIE OBJEK VAN DIE TEOLOGIE}

As die teologie wat deur die kerk beoefen word, beskou word as 'n wetenskaplike dissipline, moet die teologie homself soos enige ander wetenskaplike dissipline verantwoord oor sy eie aannames ten opsigte van die ontstaan, totstandkoming en betroubaarheid van die kennis wat dit voortbring (vgl Kotze 1992:1-26; Pieterse 1991a, 1991b, 1993; De Jongh van Arkel 1991). Samevattend, teologie moet homself kan verantwoord ten opsigte van sy eie epistemologie. Kotze (1992:4) se beskrywing van wat ons onder epistemologie behoort te verstaan, is hier ter sake: "Dit gaan dus in die term epistemologie tegelyk om die vraag na hoe 'n mens dink, waarneem en besluit, en wat die mens dink, waarneem en besluit." Hierdie "hoe" en "wat" staan egter in wederkerige verband tot mekaar. "Hoe" ek dink, waarneem en besluit, beïnvloed "wat" ek dink, waarneem en besluit, terwyl "wat" ek dink, waarneem en besluit weer "hoe" ek dink, waarneem en besluit, beïnvloed. Anders gestel: epistemologie verwys na die verhouding tussen die waarnemer en die waargenome en andersom.

Dit is duidelik dat elke mens vanuit 'n bepaalde epistemologiese raamwerk funksioneer en dat ons epistemologie 'n bepalende rol speel in ons verstaan van die 
Bybel, die belydenisskrifte, die werklikheid, asook hoe ons as mense, as gelowiges en as kerk in totaliteit, optree.

Oor "wat" gereformeerde teologiese kennis behels, is gereformeerde predikante kundiges. Hulle boekrakke is soms gevul met boeke daaroor. Die vraag is egter "hoe" daar tot hierdie teologiese kennis gekom is. Dit wil sê, hoe die mens weet wat hy weet (Kotze 1992:3-5). Hier kan konstruktivisme en die sosiale konstruksieteorie baie help in die verstaan van "hoe" daar tot kennis en uitsprake oor teologiese sake gekom word.

In die gereformeerde tradisie word die Bybel as die openbaring van God gesien waardeur God deur die mens geken kan word (vgl Heyns \& Jonker 1977:141). In hierdie tradisie is die Bybel dus die objek van die teologie. Volgens Kotze (1992:16) is hierdie keuse problematies omdat dit in 'n sekere sin die ruimte van die teologie inperk. Dit sluit die moontlikheid uit dat God ook via ander weë geken kan word, omdat kennis van God tot die taalkonstrukte van die skrywers van die Bybel beperk word.

'n Ander moontlikheid is om God tot objek van die teologie te maak. 'n Gevaarlike dualisme dreig egter by so 'n keuse, want wat word dan van die kosmos en alles wat daarin afspeel? Is die kosmos dan die objek van slegs die natuur-, sosiale en geesteswetenskappe, waar God van die kosmos losgemaak word en waar natuurwetenskappe en teologie in outonome verhoudings teenoor mekaar gestel word? Kotze (1992:16) wys op die gevaar van gemelde dualisme as hy sê: "Die tref van so 'n onderskeid lei noodwendig tot probleme, omdat dit 'n grens trek wat slegs in die oog van die waarnemer aanwesig is, en die grense vir die teologie so vernou dat dit in 'n ivoortoringbestaan gedwing word."

Bavinck (1967:11-12), Deist (1987:11), König (1973:13) en Kotze (1992:17) verstaan dit so dat die objek van die teologie nie bloot die bestudering van die Bybel, of God is nie, maar dat die teologie hom besig hou met die ganse werklikheid vanuit 'n geloofsoogpunt, dit wil sê: coram Deo (voor God se aangesig). König (1973:13) maak in hierdie verband die volgende opmerking: "Dit gaan in die teologie om meer as God in Jesus Christus." Lategan (1994:94) sê op sy beurt: "Die teologie bestudeer die ganse werklikheid vanuit die geloofsmodaliteit daarvan." Teologie word dus gesien as menslike konstruksies oor die ganse werklikheid, maar dan vanuit 'n geloofsoogpunt. 
Rossouw (1993:894-895) omskryf teologie as nadenke oor die betekenis van die openbaring vir 'n spesifieke situasie en tydvak.

\section{DIE BELYDENISSKRIFTE SE PLEK EN FUNKSIE}

Belydenisskrifte speel 'n groot rol in die Protestantse tradisie. Hierdie belydenisskrifte sluit aan by uitsprake en stellings in die Bybel en is niks anders as teologiese interpretasies en standpunte van mense wat in ' $n$ bepaalde eeu geleef en met bepaalde probleme geworstel het nie. Ons moet egter in ag neem dat die skrywers van Bybelboeke bepaalde gebeure geïnterpreteer het en dat die opstellers van die belydenisskrifte op hulle beurt daardie interpretasies gebruik om nuwe interpretasies te skep. Die gesag van hierdie geskrifte is daarin geleë dat dit deur mense geskryf is wat met God in 'n verhouding gestaan het. Voorts is hierdie geskrifte deur 'n bepaalde geloofsgemeenskap aanvaar as verteenwoordigend van hoe daardie groep oor God dink en praat.

Vanuit 'n postmoderne, sosiaal-konstruktivistiese benadering speel die belydenisskrifte in die gereformeerde teologiese diskoers 'n belangrike normatiewe rol, maar dan as 'n belangrike diskoers en nie as 'n altydgeldende dogma nie. Anders gestel: die belydenisskrifte is belangrike gespreksgenote in die teologiese diskoers, maar dan as gespreksgenote wie se stem deur alle deelnemers krities ondersoek kan en mag word (vgl Pieterse 1993:81; Louw 1993:205). Neem artikel 4 van die Nederlandse Geloofsbelydenis as voorbeeld. Hierdie artikel handel oor die Bybelboeke wat vir Protestante belangrik is, maar vermeld dan ook die verskillende skrywers soos die opstellers dit in die sestiende eeu aanvaar het. Die artikel weerspieël dus die Bybelwetenskaplike kennis van dáárdie tyd. Heelwat van hierdie standpunte word nie meer deur hedendaagse Bybelwetenskaplikes aanvaar nie. Hulle aanvaar nie meer dat Moses die skrywer van die Pentateug (eerste vyf boeke van die Ou Testament) is nie. Ook aanvaar hulle nie meer dat Paulus dertien briewe geskryf het nie.

Daar is 'n wesenlike verband tussen die veranderde metafore van 'n kultuur en die veranderde metafore van so 'n kultuur se teologie. Met ander woorde: Teologiese diskoerse (belydenisskrifte) kom nooit tot stilstand nie, is nooit onbeweeglik en onbuigsaam nie, maar altyd aan die beweeg. Mense se verstaan van God verander soos wat veranderinge in hulle kultuur plaasvind en hulle ander metafore skep. Teologie dra 


\section{Kerk en teologie in die postmoderne tyd}

die vingermerke van die tyd waarin die geskep is. Dit weerspieël die denke van die tyd waarin dit ontstaan het. André Botha (1998:96) sê in dié verband die volgende:

A change in culture, and thus in interpretative paradigms, will inevitably lead to different theological discourses. To my mind, this phenomenon is powerfully expressed in the theological discourses of the Dutch Reformed Church of the pre- and post-apartheid eras in South Africa. This implies that theology cannot be a closed and timeless system of knowledge.

Daarom is wat in die teologie voortgebring word, menslike konstrukte oor God, die wêreld en beide se verhouding tot mekaar. Die teologiese tradisie van die kerk (soos weerspieël in die belydenisskrifte) is feilbare mensewerk. Bavinck (1859-1964) het al die opmerking gemaak dat die dogmas wat die kerk bely asook die skeppings van die dogmatici, nie gelyk te stel is aan die wese van God en nie aansprake kan mak om absolute goddelike waarheid te verwoord nie.

Ten spyte van die feit dat die dinamiese taalspel iewers in die geskiedenis in ' $\mathrm{n}$ vasstaande kanon afgesluit is, het die proses van 'n dinamiese taalspel deur teologiese boeke en geloofsverhale in die mond van gelowiges voortgegaan en gaan dit nog steeds voort. Hierdie dinamiese en metaforiese taalspel, hierdie konstruering van teologie in taal, is ' $\mathrm{n}$ voortdurende, vernuwende en verrykende proses. Dit skep ruimte in die kerk dat lidmate met hulle eie metafore oor God kan werk, maar dit ook met ander s'n kan vergelyk en kan "toets". So kan elkeen van ons met ons eie metafore oor God met mekaar in gesprek tree en sodanige gesprek skep weer die moontlikheid van ' $n$ verruimende alternatiewe verstaan vir elkeen van ons se teologie. Gerkin (1991:19) maak die volgende belangrike opmerking oor 'n teologie wat voorgee dat dit met altydgeldende waarhede werk:

The interpretation and reinterpretation of a tradition such as the biblical and Christian tradition is a continuous, living, dynamic process ... in which meanings, although rooted in primary images and symbolic metaphorical themes, continually interact with the changing situations of history to create new and highly nuanced understandings of their implications .... Without such 
continual reinterpretation and metaphorical enactment, the Christian tradition would quickly become a dead tradition, unrelated to the problems of ongoing human life.

In ons ervaring en omgang met God - en in die verwoording daarvan in taal - is ons besig met ' $n$ voortgaande skeppende proses. Daarom bevat teologie 'n skeppende komponent wat nooit afgehandel is nie, maar steeds voorlopig is. Teologie loop altyd uit op nuwe interpretasies. So is ons geloofsbelydenisse byvoorbeeld deel van hierdie voortgaande teologiese refleksie (Spangenberg 1996). Die Belydenis van Belhar is 'n resente voorbeeld van hierdie voortgang en interpreterende aard van ons teologiese diskoerse.

Die belydenisskrifte speel ' $\mathrm{n}$ belangrike rol in die gereformeerde teologiese diskoers, maar dan nie as 'n altydgeldende dogma, wat beperkend en onderdrukkend is nie. Dit behoort nie te funksioneer as koue, harde, samehangende geloofsfeite in lidmate se lewens nie.

\section{DIE POSTMODERNE TYD EN DIE UITDAGINGS VIR KERK EN TEOLOGIE}

Dit is duidelik dat 'n keuse vir 'n sosiaal konstruktivistiese epistemologie, implikasies het vir die verstaan van die teologie as wetenskap, die verstaan van die belydenisskrifte, asook hoe die Bybel as basisdokument van die Christelike geloof, gehanteer behoort te word. Meer nog, dit het implikasies vir die kerk as 'n instelling in die postmoderne tyd.

\subsection{Lidmate as interpreterende waarnemers}

Wat mense as interpreterende waarnemers waarneem en beskryf, is hulle verwoording van wat hulle waarneem. Dit beteken dat daar veelvuldige kennis ten opsigte van die werklikheid bestaan. Dit stel predikante en lidmate in staat om verskillend te kan dink en optree. Dit gee aan predikante 'n bewegingsvryheid in die bediening waar hulle nie bedreig hoef te voel as 'n lidmaat se sosiale konstrukte oor God so bietjie anders as ander lidmate of die predikant s'n is nie. 
Die Bybel as basisdokument van die Christelike geloof is self interpretasies van ervarings (en soms ook interpretasies van interpretasies). God is groter as die interpretasies van die skrywers van Bybel (Deist 1986). Dit beteken egter nie dat die Bybel deur die predikant as interpreterende waarnemer uitgerangeer kan word tot 'n minderwaardige rolspeler in die teologie nie. Aan die ander kant beteken dit egter ook dat die metafore oor God nie beperk kan word tot die bladsye van die Bybel nie. Daar bestaan ook ander metafore oor God. Tog, die spesifieke gekose metafore van 'n sekere geloofsgemeenskap is vir so 'n geloofsgemeenskap normatief, maar sluit nie dialoog oor die houdbaarheid van sodanige " normatiewe" metafore uit nie.

\subsection{Een diskoers of vele diskoerse?}

Op voetspoor van Kotze (1995:21) word die term "postmoderne diskoers" gekies in plaas van die term "postmodernisme". Dit is 'n aanduiding daarvan dat die postmoderne diskoers inklusief en oop is vir gesprek, en dat modernisme en bepaalde metafore van modernisme nog ' $n$ integrerende deel van die postmoderne gesprek is.

Daar word dus gekies vir 'n "beide/en”, eerder as 'n “óf/óf” posisie en die motivering is daarin geleë dat postmodernisme nie weer 'n "grand narrative" wil word nie. Vir die teoloog is die pluspunt van 'n teologie wat met die ganse werklikheid werk daarin geleë dat dit nou moontlik is om met 'n verskeidenheid van ander diskoerse in gesprek te tree wat dan ook die teologie meer kultuursensitief maak en sodoende verseker dat die teologie relevant en dinamies bly.

Daar word dus nie 'n teenoorposisie ten opsigte van ander diskoerse ingeneem nie, maar dit word gesien as geleenthede om met sodanige diskoerse in gesprek te tree om sodoende die eie gesprek te verruim en te verbreed. In sodanige gesprek gaan dit nie daaroor om mekaar te wil verander nie (dit sal vanself plaasvind in die proses van die gesprek), maar eerder om mekaar te probeer verstaan.

Alhoewel die Bybel as die basisdokument van die Christelike geloof aanvaar word, maak die postmoderne diskoers se uitgangspunt van "beide/en" dit dus moontlik dat die Bybel en ander metaforiese spreke oor God, ruimte het in die teologiese diskoers. Die deur vir 'n nuwe dialoog tussen godsdienstige en ander diskoerse staan dus oop. 
Die "beide/en" posisie maak dit moontlik dat postmoderne Christene nie so maklik soos modernistiese Christene gemarginaliseer kan word nie, omdat postmoderne Christene vir hulle besef net so 'n geldende stem het soos enige van die ander stemme. Vanuit 'n "beide/en" posisie wil die postmoderne diskoers dus vermenigvuldig en nie reduseer nie (Stiver 1995). Kennis, verstaan en betekenis kom juis in so 'n dialogiese situasie tot stand.

\subsection{Eendimensionele waarheid of meerdimensionele waarheid?}

Die postmoderne diskoers se epistemologiese uitgangspunt dat objektiewe kennis onmoontlik is en dat 'n "beide/en", eerder as 'n "óf/óf" posisie verkies word, lei daartoe dat die gedagte van 'n enkele voltooide waarheid bevraagteken word en ons aldus uitgedaag word om met groter onsekerheid te leef wat ons kennisuitsprake betref. Die luuksheid van 'n vasgestelde raamwerk bestaan (nie meer) nie. Of dit positief of negatief beoordeel moet word, of dit ' $n$ geleentheid of bedreiging is, is deel van die gesprek. Pieterse (1993:15) maak die volgende opmerking: "So kom die postmoderne mens te staan voor 'n heilige, onuitputlike en oorvloedige werklikheid." En sou bygevoeg kon word: 'n heilige, onuitputlike en oorvloedige waarheid, of miskien: 'n heilige, onuitputlike, oorvloedige en meerdere ervaring van God. Tracy (1994) se gedagte om in die teologie 'n oog te hê vir 'n "ander", om 'n oog te hê vir verskillende denke oor spiritualiteit is hier van belang.

\subsection{Een ervaring van God of meerdere ervarings van God?}

Binne die postmoderne diskoers word nuwe lewens- en toekomsmoontlikhede vir die kerk geskep. Een daarvan is dat die weg geopen word vir 'n metafories- en simboliesmeerduidige siening en ervaring van God en die menslike werklikheid (Du Toit 1988:39). Die postmoderne vereiste dat alle deelnemers in enige dialoog gelyk en oop vir mekaar moet wees om sodoende saam kennis te konstrueer, maak die sogenaamde "not knowing" keuse wat Anderson en Goolishian (1992:27) aanbeveel, sinvol.

As gevolg van hierdie posisie kan die predikant (en die kerk) nie as die "expert knowledge bearer" beskou word nie. Voorts is predikante (en die kerk) nie meer die verhewe kenners wat aan lidmate kan voorskryf hoe dinge presies werk en hoe nie, of hoe 


\section{Kerk en teologie in die postmoderne tyd}

God ervaar moet word en hoe nie. Die predikant is nie die senior ekspert en die lidmaat die junior onkundige/oningeligte nie. Anders gestel: die kerk se sogenaamde verhewe kennis van die teologies-etiese diskoerse kan nie as die enigste geldende waarheid funksioneer nie.

Die kerk se kennis moet nie 'n bron van mag word waardeur lidmate in gesprekke beheer word nie. Indien dit die geval is, gaan dit om hiërargie en beheer waar die dominee die waarnemer en ekspert is en die lidmaat die geobserveerde en die "dom skaap". Wanneer die predikant en die kerk afstand doen van hierdie posisie, kom hulle nader aan die lidmaat. Hoffman (1992:16) wat praat vanuit 'n terapeutiese hoek, stel dit soos volg: "The attempt to honor where people stood and how they saw things became a constant reminder that participants in therapy had their own expertise. A value was placed, thereby, on a participatory experience validated by the expression of many voices, rather than reliance on the voice of an expert."

Bogenoemde uitgangspunte bied 'n konteks vir ware gesprek en ontmoeting tussen die predikant en die lidmaat, sonder dat die predikant as deskundige, 'n monoloog van die gesprek maak. Vanuit 'n postmoderne posisie neem die predikant deel aan 'n gesprek wat wil oopmaak en nie wil beperk en afsluit nie. Dit word 'n gesprek waar betekenisse ruimte kry, verbreed, geskuif en verander word (Anderson \& Goolishian 1988:381). Dit beteken egter nie dat predikante in die gesprek met lidmate passiewe toeskouers of luisteraars is nie (Dill 1996). Hulle is aktief in gesprek met lidmate en verduidelik hoe hulle vanuit hulle vakkennis die teologiese diskoerse (die Bybel en die belydenisskrifte) verstaan.

Dit word egter op so 'n wyse gedoen dat die ervaring, deskundigheid, standpunte en gevoelens van lidmate erken word. Daar word ook nie met lidmate gepraat deur middel van uitroeptekens nie, maar eerder deur middel van vraagtekens. Deur so in vraagtekens te praat, word die geleentheid geskep dat predikante hulleself heeltyd in 'n posisie van leer plaas. So word predikant en lidmaat die geleentheid gegun om nog saam te mag wonder oor God en dalk nog, wie weet, deur God verras te kan word.

Die gevolg hiervan is dat lidmate selfvertroue en vrymoedigheid kan hê om hulle teologiese konstruksies en Godservarings op die tafel te plaas. Ten diepste gaan dit daarom dat daar respek vir lidmate se stories moet wees - al is hulle stories anders as die 
predikant s'n, en al dink lidmate anders oor die lewe en selfs oor God as die predikant. Die klem dat lidmate se teologiese uitsprake en ervarings "feitelik korrek" en logies samehangend moet wees, en dat lidmate die kerklike leerstellings presies "reg moet weet en moet kan nasê", word versag.

Lidmate word die geleentheid gebied om hulle geloof volkome uit te leef as hulle persoonlike geloofskonstruksie en die predikant word die ruimte gebied om verantwoordelike geestelike hulp en leiding te gee volgens die spesifieke behoefte in die spesifieke omstandighede.

In feite kom dit daarop neer dat, hoewel die predikant die Bybel aanvaar as God se Woord in mensetaal en die belydenisskrifte van die kerk as normatief sien, dit nie beteken dat dit op ander afgedwing moet word nie. In gesprekke met mekaar word nuwe kennis en nuwe betekenis - en selfs meerduidige ervaring van God - verwoord.

Lidmate kan net gehelp word as die gesprek tussen predikant en lidmaat 'n voortgaande proses is waar lidmate beskou word as gespreksgenote. Volgens die gekose postmoderne denkraamwerk is dialoog die enigste manier om tot nuwe betekenis en nuwe alternatiewe te kom (vgl Dill 1996; Gerkin 1991; Hoffman 1990; Monk 1996; Wylie 1994).

\section{RELATIVISME}

Die vraag is of dit alles nie tot relativisme sal lei waar chaos die uiteindelike eindpunt is, omdat die vryheid en reg van die individu nou tot norm verhef word nie. Kotze (1992:29) maak die opmerking dat konstruktivisme en die sosiaal konstruksieteorie ruimte skep vir die belangrike rol wat keuses (en daarmee saam, waardes op grond waarvan keuses uitgeoefen word) in menslike gedrag speel. Waarnemers het 'n keuse watter waarde hulle aan dinge heg. Elkeen is verantwoordelik vir sy/haar eie konstruksies en die dade wat uit hierdie konstruksies voortvloei. Kotze (1992:60) verwoord dit so: "Die gedagte van alternatiefskepping vir die ander korreleer met die gedagte van ruimteskepping vir die ander. Dit is juis die wyse waarop God met die mens in verhouding tree deur vir hom ruimte te skep om te kan lewe en self verantwoordelikheid vir sy lewe te kan aanvaar." 


\section{Kerk en teologie in die postmoderne tyd}

Sosiaal gekonstrueerde diskoerse wat die geleentheid bied vir ander realiteite, ander standpunte en ander mense, naas die eie en die self, open die weg vir 'n etiese keuse vir die liefde wat gerig is op diensbaarheid in belang van die naaste. Ons as mense is verantwoordelik vir die keuses wat ons uitoefen. Waardes en menslike verantwoordelikheid is dus uiters belangrik in die postmoderne tyd.

Konstruktivisme en die sosiaal konstruksieteorie as postmoderne begrippe beklemtoon dus die etiese verantwoordelikheid van mense se sienings en handelinge. 'n Verdere punt is dat waardes en normatiewe reëls van 'n betrokke gemeenskap, kennis beïnvloed. Gergen (1985:14) stel dat dit nie hier gaan oor "anything goes" nie, aangesien kennis-sisteme afhanklik is van 'n gemeenskap wat dit deel. Dit is ook in hierdie lig wat die belydenisskrifte wat predikante onderteken het, beskou moet word. Predikante onderteken die belydenisskrifte as lid van 'n spesifieke geloofsgemeenskap en alhoewel predikante hulle die reg veroorloof om verder oor die ontstaan, asook die inhoud van die geskrifte na te dink, weerhou dit hulle nie daarvan om hierdie geskrifte nog steeds as rigtinggewend te beskou nie.

\section{SLOT}

Dit is voor die hand liggend dat baie teoloë en predikante die postmoderne paradigma en die implikasies daarvan vir die kerk en die teologie as radikaal en bedreigend sal ervaar. Die broodnodige gesprek oor die postmoderne paradigma en die betekenis en gevolge wat dit vir die kerk en die teologie inhou, word veral bemoeilik deur die feit dat Afrikaanssprekende kerke nog vanuit 'n modernistiese paradigma opereer, terwyl die postmoderne tyd reeds aangebreek het.

Van Aarde (1995) is van mening dat die teologie nie kan hoop om voort te bestaan in sy modernistiese baadjie nie. Ons sal moet kennis neem van die postmoderne paradigma en die gevolge wat dit vir die kerk en die teologie inhou. Terselfdertyd sal daar vasgehou moet word aan die openbaring van God en die getuienis daaroor in die Bybel. Die nuwe situasie skep nuwe geleenthede vir die kerk en die teologie, want dit skep 'n nuwe openheid vir geloof in God waar elkeen steeds verras kan word deur nuwe insigte. In hierdie teologie is daar baie ruimte - vir God en vir mense. 
Dill (1996:254) moet gelyk gegee word as hy sê dat die uitdagings van die postmoderne era enorm is en dat die teologie (Dill verwys spesifiek na die praktiese teologie) homself gou as irrelevant in die vinnig veranderende konteks kan bevind. As die uitdagings wat die postmoderne tyd bied, wel positief aanvaar word, voorsien ons dat daar ruimte vir gesprekke oor God en sy onbegrensde liefde kan ontstaan.

Epistemologiese paradigmas en die postmoderne paradigma is die produk van sosiale diskoerse en alle paradigmas het 'n beperkte raklewe. Daarom sal ook die postmoderne paradigma en die daarmee samehangende epistemologie, eendag in die toekoms vervang word deur iets anders en sal dit deel word van die geskiedenis van diskoerse. Geloof in God sal egter deel van die kerk se diskoers bly. In die postmoderne tyd val die klem egter baie sterk op die voorlopigheid van ons kennis en die kerk sal daarom ook in 'n laer toonaard moet praat. Jaap Zijlstra (in Overduin 1972:29) verwoord hierdie laer toonaard treffend in 'n gedig met die titel "Vergeef". Dis in hierdie laer toonaard dat die skrywers van hierdie artikel ook hulle nadenke aanbied:

\section{Vergeef}

Vergeef mij dat ik met mijn kleine woorden

meedoe en stal zeg

en ster

en dat ik in drie kleine letters

God zeg

en $U$ denk te noemen daarmee.

Het water is veel te diep

tussen mij en de stal

en de ster is te hoog

ik verspreek mij wanneer ik $U$ noem.

Vergeef mij dat ik met mijn kleine woorden

toch meedoe en stal zeg

en ster

en dat ik in drie kleine letters

God zeg

en $U$ denk te noemen daarmee. 


\section{Literatuurverwysings}

Anderson, H \& Goolishian, H 1988. Human systems as linguistic systems: Evolving ideas about the implications for theory and practice. Family Process 27(4), 37393.

Anderson, H \& Goolishian, H 1991. A collaborative language systems approach. Paper given at the narrative and psychotherapy conference, Houston Texas.

Anderson, H \& Goolishian, H 1992. The client is the expert: A not-knowing approach to therapy, in McNamee, S \& Gergen, K J (ed), Therapy as social construction. London: Sage.

Bavinck, H 1967. Gereformeerde dogmatiek (Tweede deel). Kampen: Kok.

Berger, P L \& Luckmann, T 1967. A social construction of reality. New York: Doubleday.

Botha, A 1998. Pastoral therapy and extra-marital affairs: A narrative approach. $\mathrm{PhD}$ Thesis, University of South Africa.

Bottum, J 1994. Christians and postmoderns. First Things 40, 28-32.

Brueggemann, W 1993. Texts under negotiation: The Bible and postmodern imagination. Minneapolis, MN: Fortress.

Deist, F E 1986. Kan ons die Bybel dan nog glo? Pretoria: JL van Schaik.

Deist, F E 1987. Relatiwisme en absolutisme: Kan dit oorkom word? Oor "Bybelse" en "dogmatiese" teologie, in Prinsloo, W S \& Vosloo, W (red), Ou Testament Teologie: Gister, vandag en môre, 1-17. Pretoria: NG Kerkboekhandel.

De Jongh van Arkel, J T 1991. Ekosisteemdenke as meta-teorie in die praktiese teologie. Praktiese Teologie in Suid-Afrika 6(1), 61-75.

De Villiers, P G R 1991. The end of hermeneutics? On New Testament and postmodernism. Neotestamentica 25(1), 145-156.

Dill, J 1996. 'n Basisteorie vir pastorale terapie in die lig van postmoderne epistemologie. PhD Tesis, Universiteit van die Oranje Vrystaat.

Dockery, D S 1995. The challenge of postmodernism, in Dockery, D S (ed), The challenge of postmodernism: An evangelical engagement. Wheaton: Victor Books. 
Du Toit, C 1988. Aspekte van die postmodernistiese idioom in die teologie. Theologia Evangelica 70 (1), 36-50.

Efran, J S \& Lukens, M D 1985. The world according to Humberto Maturana. The Family Therapy Networker 9, 23-25.

Efran, J S \& Lukens, M D 1990. Language, structure and change. New York: Norton.

Gergen, K J 1985. The social constructionist movement in modern psychology. American Psychologist 40, 266-275.

Gergen, K J 1991. The saturated self: Dilemmas of identity in contemporary life. USA: Basic Books.

Gergen, K J 1994. Realities and relationships: Soundings in social construction. Cambridge, MS: Harvard University Press.

Gergen, K J \& Davis, K E 1985. The social construction of the person. New York. Springer.

Gerkin, C V 1991. Prophetic pastoral practice: A Christian vision of life together. Nashville,TN: Abingdon.

Henry, C F H 1995. Postmodernism: The new spectre, in Dockery, D S (ed), The challenge of postmodernism: An evangelical engagement. Wheaton: Victor Books.

Heyns, J A \& Jonker, W D 1977. Op weg met die teologie. Pretoria: NG Kerkboekhandel.

Hoffman, L 1990. Constructing realities: An art of lenses. Family Process 29(1), 1-12.

Hoffman, L 1992. A reflexive stance for family therapy, in McNamee, S \& Gergen, K J (eds), Therapy as social construction. London: Sage.

König, A 1973. Die teologiese wetenskap, in Eybers, I H, König, A \& Stoop, J A (red), Inleiding in die teologie, 1-36. Pretoria: NG Kerkboekhandel.

Kotze, D J 1992. Verantwoordelikheid as antropologiese essensie. Pretoria: Universiteit van Pretoria.

Kotze, E 1995. The social construction of a family therapy training programme. Johannesburg: RAU.

Lategan, L O K 1994. Die voorstel van 'n metodologiese diskoers vir die skryf en lees van 'n kerkhistoriese teks. NGTT 35(1), 93-100. 
Louw, D J 1993. Pastoraat as ontmoeting: Ontwerp vir 'n basisteorie, antropologie, metode en terapie. Pretoria: RGN.

Maturana, H R \& Varela, F J 1980. Autopoiesis and cognition: The realization of the living. Dordrecht: Reidel.

Maturana, H R 1987. The tree of knowledge: The biological roots of human understanding. Boston, MS: Shambhala.

Monk, G 1996. Narrative therapy in practice: The archaeology of hope. San Francisco, CA: Jossey-Bass.

Overduin, J 1972. Praten zonder antwoord? Gedachten over het Onze Vader. Kampen: Kok.

Pieterse, H J C 1991a. Die wetenskapsteoretiese grondslag van die Praktiese Teologie. Praktiese Teologie in Suid-Afrika 6(1), 38-51.

Pieterse, H J C 1991b. Praktiese Teologie as praktiese wetenskap binne die teologiese fakulteit. Praktiese Teologie in Suid-Afrika 6(2), 249-254.

Pieterse, H J C 1993. Praktiese Teologie as kommunikatiewe handelingsteorie. Pretoria: RGN.

Rossouw, G J 1993. Theology in a postmodern culture: Ten challenges. HTS 49(4), 894907.

Shotter, J 1993. Conversational realities: Constructing life through language. London: Sage.

Spangenberg, I J J 1996. Die Ned Geref Kerk, die boek Jona en religieuse pluralisme. Ongepubliseerde voordrag gelewer tydens ' $n$ kongres van die Ou-Testamentiese Werkgemeenskap van Suider-Afrika. Stellenbosch.

Stiver, D R 1995. The uneasy alliance between evangelicalism and post-modernism: A reply to Anthony Thiselton, in Dockery, D S (ed), The challenge of postmodernism: An evangelical engagement. Wheaton: Victor Books.

Tracy, D 1994. Theology and the many faces of postmodernity. Theology Today 51(1), 104-114.

Van Aarde, A G 1990. Holisme as 'n postmodernistiese filosofie in teologiese lig. HTS 43(3), 293-311. 
Van Aarde, A G 1995. Kerk en teologie op pad na die derde millennium: Gedagtes oor die kontekstualisering van die dialektiese teologie in 'n plurale samelewing. HTS 51(1), 39-57.

Van Niekerk, A 1994. Om oor God te praat: Analogiese spreke as skepping en onthulling. NGTT 35(2), 279-295.

Von Foerster, H 1984a. Observing systems. Seaside: Intersystem Publications.

Von Foerster, H 1984b. On constructing a reality, in Watzlawick, P (ed), The invented reality. New York: Norton.

Wylie, 1994. Panning for Gold. The Family Therapy Networker 18(6), 40-48. 